\title{
REVISTAVISUAIS
}

REVISTADO PROGRAMA DE PÓS-GRADUAÇÃO EMARTES VISUAIS DA UNICAMP

\section{Camilo José Cela}

e a

fotografia

Fernando Cury de Tacca

Brasil. Professor livre-docente no Instituto de Artes da Unicamp.

Realizou pós-doc na Universidad Complutense de Madrid (Bolsa Fapesp)

em 2011 na Universidad de Zaragoza (2018/19 - Bolsa Fapesp).

fernandodetacca@gmail.com 


\section{Camilo José Cela e a fotografia}

\section{Resumo}

Camilo José Cela foi um dos escritores espanhóis mais importantes do século passado, tendo recebido o Prêmio Nobel de Literatura em 1989, entre outros, e teve uma relação com a fotografia muito profícua desde o final dos anos 40 . Com muitos livros paradigmáticos publicados entre os quais muitos propiciam uma atmosfera de realidade imagética, entretanto, construída pela ficção, sendo assim um pioneiro na exploração de uma relação complementar entre imagem-texto em seu processo criativo. Manteve sempre uma produção literária intensa e entre outros podemos citar a criação do Editorial Alfaguara e da revista Papeles de Son Armadans. O artigo analisa as suas obras no intercruzamento entre fotografia e literatura.

\section{Palavras-chaves}

Camilo José Cela; fotografia; literatura.

\section{Resumen}

Camilo José Cela fue uno de los escritores españoles más importantes del siglo pasado, recibió el Premio Nobel de Literatura en 1989, entre otros, y tuvo una relación muy fructífera con la fotografía desde finales de la década de 1940. Con muchos libros paradigmáticos publicados entre los cuais muchos crean una atmósfera de realidad imaginaria, sin embargo, construida por la ficción, siendo pionera en la exploración de una relación complementaria entre la imagen y el texto en su proceso creativo. Siempre ha mantenido una intensa producción literaria $y$, entre otros, podemos mencionar la creación de la Editorial Alfaguara y la revista Papeles de Son Armadans. El artículo analiza sus obras en la intersección de la fotografía y la literatura.

\section{Palabras clave}

Camilo José Cela; fotografía; literatura. 


\section{Entre o elogio à fotografia e livro de viagem}

Em abril de 1998, o fotógrafo Alberto Schommer, quando na sua admissão na Real Academia de Bellas Artes de San Fernando, apresentou uma conferência que se intitulava "Elogio a la Fotografía". Nesse longo texto traz suas referências visuais de conhecidos fotógrafos, por todas épocas, por também icônicas imagens e pela história da fotografia. Perpassa também seu percurso profissional e pessoal. Em determinada passagem faz uma alusão ao fotógrafo Eikoh Hosoe e também ao escritor espanhol Camilo José Cela:

Luego fuimos amigos y nos hemos comprendido. Querido Eikoh Hosoe te expreso mi gratitud por tu obra "Muerto por las rosas" y a ti Mishima que te hiciste desaparecer porque no podías superar tu poesía que era demasiada vida para vivirla. Porque en el Arte, en esta asignatura, es bueno aceptar las carencias, y como escribe Cela, "... en el recodo del sendero de la vida se hacen sinceras las humildades..." ¡Cuánta sutileza de ánimo hay que ejercer para superar el verse rodeado de tanta hermosura, tanta maravilla como la aportada por la Fotografía... y yo siempre aprendiz quiero sobre todo descubrir al hombre, porque no hay duda que el centro del Universo es el Hombre y la fotografía que es la Realidad se apoya sin duda en él. (SCHOMMER, 1998, p. 15)

Chama-nos a atenção que José Camilo Cela é citado duas vezes no texto de Schommer.

Em outra passagem ele faz uma referência aos instrumentos de criação:

Siento que vivo más a través de la imagen, más intensamente y recogiendo otro párrafo de Cela: "No puedo arrepentirme de haber visto pasar la vida entera con una pluma en la mano..." yo digo en mi caso, con una cámara del tiempo, que me aproxima a los hombres en su alegría, su intimidad, su desesperación. (SCHOMMER, 1998, p. 21)

Entretanto, o autor não faz nenhuma citação direta a um texto com um título quase idêntico, publicado por Cela em 1948: "Elogio de la Fotografía"1. Esse texto de Cela foi posteriormente publicado em $1990^{2}$ dentro do conjunto de sua obra. As referências poéticas de Cela poderia ser agregada e ter sido lembrada o seu texto e também a sua relação com a fotografia, mas não me cabe julgar os caminhos escolhidos por Schommer, somente fazer ver a presença de Cela na fala de um fotógrafo quando se apresenta à academia mais importante de artes da Espanha. Me interessa nesse artigo trazer a contribuição de José Camilo Cela para a relação entre fotografia e literatura. 
Em seu texto, Cela recorda de uma câmera que ganhou quando criança ( não cita a marca, mas seu formato, tipo caixão), diz ele logo no início: “Vaya por delante que el cronista ni es fotógrafo ni tiene una sola de las múltiples aptitudes que se precisan para serlo" (Cela, 1990, pag. 322); principalmente pelas imagens de cabeças cortadas e tremidas, e de sua falta de jeito, ao mesmo tempo, enfatiza que pode ser essa sua não destreza com o aparelho o fundamento ou a raiz de sua “... admiración sin limites que el cronista siente por tal arte". Assim, o cronista, personagem de seu texto, ou ele mesmo, se coloca como um possível intermediário entre a palavra e a imagem.

O cronista, Cela, percebe já em 1948 que não se poderia adentrar a imagética fotográfica somente buscando as suas objetividades positivistas, e a entende como "un complejo arte subjetivo". Nos parece que Cela estava sincrônico às discussões sobre o fotográfico, pois nesse momento Otto Steinert estava criando o grupo Fotoform, seguida de exposição paradigmática em 1951, quando questiona o caráter documental e os academicismos germinados pelo pictorialismo, para propor conceitualmente e na prática o que chamou de fotografia subjetiva. Em seguida, acentua que o aparelho somente faz sentido se intencionalmente, como irá dizer Flusser muitos anos depois, ao colocar o sujeito fotógrafo como o articulador do código, diferenciando o olho do fotógrafo da ideia de objetivo/lente, e sua mão/dedo da mecânica do disparador.

Cela faz alusão as algumas fotografias e fotógrafos, e no caso do fotógrafo Nicolás Müller ${ }^{3}$, perpassa uma exposição do artista e seus retratos de conhecidos e desconhecidos, e diz que que as imagens lhe revelavam aspectos mais além do físico, e sim da personalidade dos retratados, mesmo que muitos deles o cronista os conhecia de convivência muito próxima.

O cronista, personagem autocentrado de Cela, entra no campo das possíveis leituras posteriores que a imagem fotográfica propicia, mas interessa aqui sua referência ao fotógrafo austríaco Karl Wlasak, que fotografou Castilla. E lembra que, junto com o fotógrafo, fizeram uma viagem a pé pelos campos, vales e pelos altos das montanhas; uma viagem que implicava muito menos que origem e destino, mas pelas paisagens e experiências pessoais. 0 cronista volta à sua experiência de estar lá, para um estar aqui frente às imagens, e perceber que, aos olhos do fotógrafo outras impressões lhe foram atiçadas: "Pues bien; a pesar de la lenta marcha y de la cuidadosa atención, el cronista 
no penetro em el más hondo sentido de la paisaje que recorriera hasta que, de regresso a la ciudad, repitió la excursión a través de la fotografias de Wlasak". (CELA, 1990, p. 324)

Na década de quarenta, escreveu quatro novelas, inclusive seu primeiro romance e internacionalmente conhecido "La familia de Pascual Duarte" (Burgos: Aldecoa, 1942), e também uma obra paradigmática, "La Comena" (Buenos Aires: Emecé, 1951), essa última totalmente alterada pela censura franquista e que foi proibida antes de publicar, e sua primeira edição ocorreu na Argentina.

Também em 1948, ano de publicação de seu texto sobre fotografia, Camilo José Cela publicou um de seus livros mais conhecidos, Viaje a la Alcarria (1948, com 50 fotografias de Karl Wlasak), resultado de sua viagem a essa região ao norte de Madrid, em Castilla - La Mancha. Entre 06 e 15 de junho de 1946, Cela percorreu essa região a pé como um viajante diretamente em contato com as comunidades rurais, e esteve acompanhado, conforme seu próprio texto citado acima:

Las notas del cuardeno de viaje del escritor, su correspondencia y los propios artículos de El Español certificam que el viajero contó con la companía del fotógrafo Karl Wlasak y de Conchita Stichaner, quienes hicieron las fotografias de la primera edición y de uma amplia gavilla que le sirvió de documentación a Cela para la redacción definitiva del Viaje, aunque no vieran la luz em el tomo de la Revista de Occidente. (VÁSQUEZ, 2008, p. 93)

Antes da publicação do livro, Vásquez afirma que cinco de suas crônicas foram enviadas para publicação na Revista de Occidente, acompanhadas de fotos de Wlasak, e somente três foram publicadas, e as outras Cela recusou-se a publicar, por motivos de conflito com os editores do semanário. Em Viaje a la Alcarria, Cela dialoga com o gênero dos textos de viajantes, tradicional na literatura, desde tempos gregos, como a Odisseia de Homero, e de muitos outros escritores de muitos tempos e lugares. Em seus outros textos desse momento, sua escrita é caracterizada pelos estudiosos de Cela como uma narrativa dentro do estilo "tremendismo"4. Para Vásquez, o livro de viagens de Cela se desgarra dessa tradição:

Este Viaje a la Alcarria, editado por Revista de Occidente con bela colección de fotos de Karl Wlasak, es el libro de Cela que más me interessa. Siento mucho no ser uno de los admiradores incondicionales de La Família de Pascual Duarte. Pero en esta novela 
había eso que llaman "una gran pluma". Y esa pluma, después de varios libros vacilantes en los que el autor buscaba su caminho con téson, pero manteniéndose em la línea efectista del "tremendismo", ha escrito por fin un libro encantador, con nervio natural y sin forzar la máquina. Un hombre se pasea por unos pueblos españole. (VÁSQUEZ, 2008, p. 107)

A primeira edição do livro, em 1948, pelo Editorial Revista de Occidente, de Madrid, tem como título Las Botas de Siete Leguas. Viaje a la Alcarria. A edição do Editorial Destino, de Barcelona, de 1954, pelo mantém o título original e acrescenta em sua terceira edição um complemento, Las Botas de Siete Leguas. Viaje a la Alcarria. Con los versos de su cancioneiro cada um en su debido lugar, com a poesia que Cela publicou em um pequeno livro Cancionero de la Alcarria (San Sebastian, Editorial Escelicer, 1948). Em 1966, com 48 fotografias de Karl Wlasak e com o cancioneiro, a publicação do Editorial Alfaguara traz somente o título Viaje a la Alcarria. Em 1989 Camilo José Cela recebeu o Prêmio Nobel de Literatura, e nesse mesmo ano o livro foi republicado pelo Editorial Destino/Áncora y Delfin, e para Cela essa edição como a definitiva, depois de suas muitas variações editoriais ${ }^{5}$.

Como uma indicação de sua epopeia, Cela coloca duas epígrafes. Na página inicial cita o poeta estadunidense William Cullen Bryant, como referência à poética da natureza, e logo em seguida uma pequena passagem do épico e anônimo Cantar de mio Cid, considerado primeira grande obra extensa da literatura espanhola (por volta do ano 1.200), e aqui, uma citação sobre a geografia, Alcarria. Aqui, entendemos sua carta homenagem a Gregorio Marañón no início do livro quando diz: “... porque este libro no es uma novela, sino más bien uma geografia", e complementa: "En novela vale todo, con tal de que vaya contado con sentido común, pero em la geografia, como es natural, ya no vale todo, y hay que decir siempre la verdade, porque es como una ciência" (CELA, 1966, p. 09). Marañon morre dois anos depois da primeira edição de Viaje a Alcarria, em 1960.

As fotografias de Wlasak acompanham o texto e muitas vezes com literalidade, quando a narrativa passa por paisagens rurais e urbanas, pela arquitetura, e ganha alguma relevância nos enquadramentos de personagens dos pequenos pueblos por onde passa "el viajero". Uma Espanha rural, de produção agrícola, perto da Capital, 
Madrid, é percorrida pelo viajante que relata encontros com pessoas, situações, que são alimentados pela prosa e pelo diálogo que o escritor traz de forma realista na sua narrativa. Na relação texto e imagem, somos levados da escritura à imagem, e somente em poucas destas podemos nos desgarrar do texto para alimentar o imaginário da escrita pela potência da imagem, acrescentado algo para além de Cela.

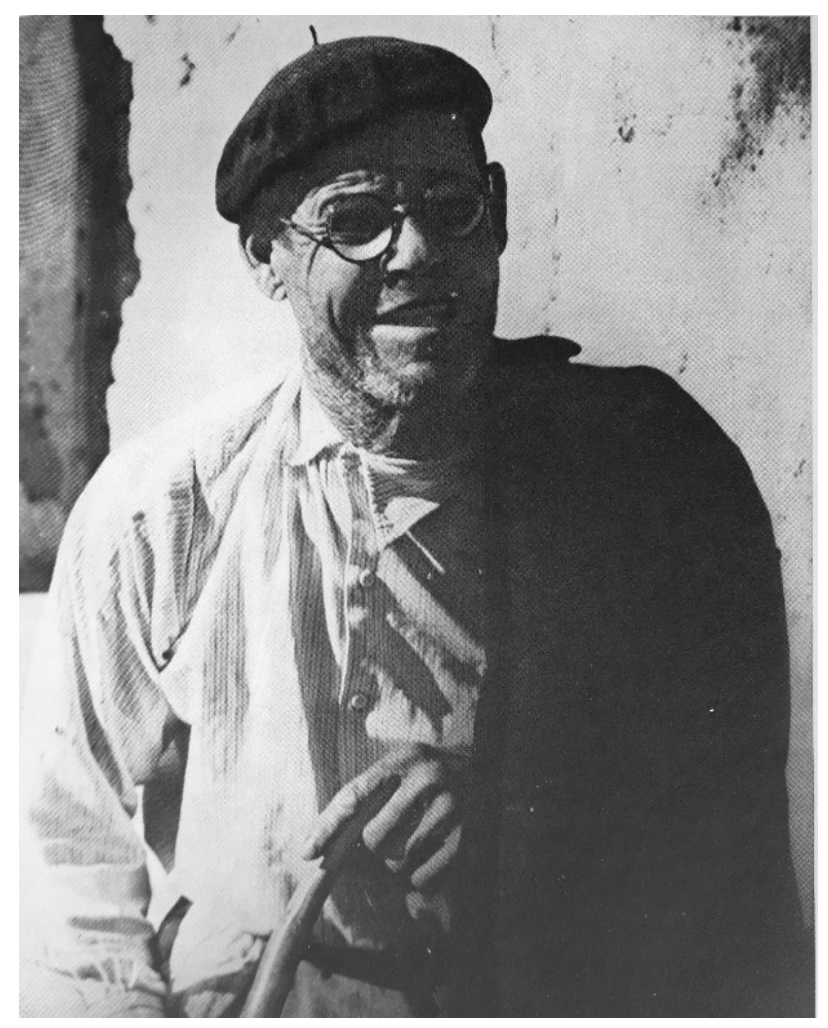

Figura 01 - Viaje a Alcatria. Foto de Karl Wlasak

Entre caminhos encontra um senhor, “Un viejo médio desdentado, con gafas, boina y cayado, com barba de seis días y la chaqueta de pana echada sobre el ombro, a la torera, habla con el viajero", que lhe conta de uma viagem a Madrid para operar de cataratas depois da guerra, e lhe pergunta de algumas pessoas do lugar onde operou, Cela não os conhece e indaga a si mesmo que o velho então duvidasse que vinha realmente de Madrid. E então o escritor dá voz ao personagem e apresenta as tristes histórias pessoais, e o seu retrato, em página inteira, complementa o relato com uma imagem que nos parece viva e digna do velho camponês; quase ouvimos sua voz mesmo na mudez fotográfica: 
El tiempo acaba con todo, ya ve usted. Cuando me quedé inútil, mi hijo Paco andaba por los doce años aún cumplidos. Le di la herramienta y le dije: Aquí tienes los aperos; el campo ya sabes dónde está. El hijo es bueno y, desde entonces, es le que lleva todo. Nosotros, ¿sabe usted?, somos los dos solos; la madre morió cuando nasció el muchacho. Al Paquito más le vale trabajar lo que es suyo; vamos, es lo que pienso yo. (CELA,1966, p. 176)

No início do livro, Cela nos relata sua casa, a preparação para a viagem ainda com escuridão da madrugada e seus ruídos urbanos, sua despedida da família, e relata o caminho percorrido a pé de sua casa até para a estação de Atocha, passando por lugares conhecidos da cidade e pelos personagens do início do dia; e é quando escritor e personagem "viajero" começam sua fusão em entidade literária. Nesse início, uma foto de seu escritório, com sua jaqueta, livros, etc, mostram o desgarramento do intelectual que abandona seu lugar de ofício para um encontro que lhe faz necessário com a gente de seu país.

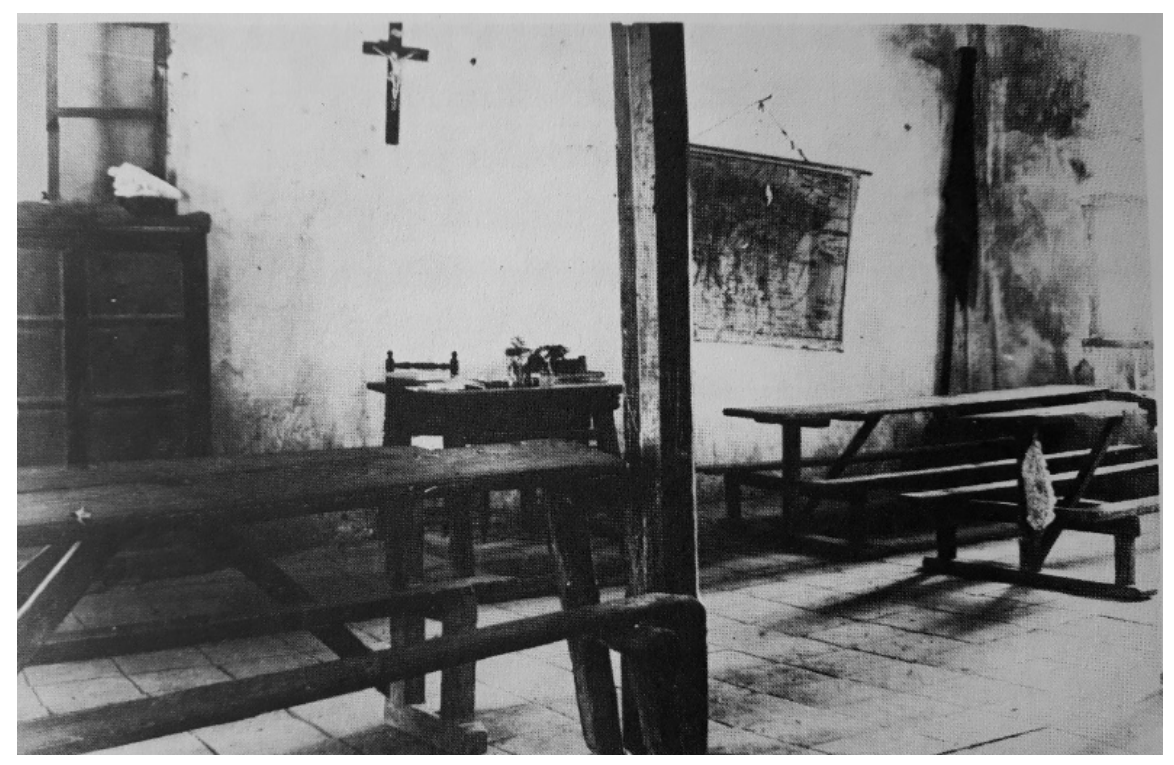

Figura 02 - Viaje a Alcatria. Foto de Karl Wlasak

A foto de uma escola de Casasana, vazia, com seus bancos comuns para alunos/as, e provavelmente de muitas séries todas juntas, como ocorre em escolas rurais de uma só professora, permite-nos um lugar para além da descrição de Cela. Coloca uma 
questão sobre o vazio, sobre a educação e sobre os signos do poder instalados na pequena sala (signos lembrados, sem críticas diretas, por Cela: crucifico, mapa e bandeira da Espanha). 0 texto do viajante não questiona o ensino, mostra a decadência, e a foto do vazio acrescenta a crítica indireta: "La escuela de Casasana es uma escuela impresionante, misérrima, con los viejos bancos llenos de parches y remiendo, las paredes y el techo con grandes manchas de humedad, y el suelo de losetas movedizas, mal pegadas" (CELA, 1966, p. 193). A fotografia de Wlasak nos coloca frente a uma ausência.

\section{Fotografías al minuto}

Tendo esse título acima, foi publicado em 1972 o livro de crônicas urbanas de Camilo José Cela acompanhado de 77 fotografias de Henrique Palazuelo, e 73 relatos. Logo no prólogo, Aviso para descarriados ${ }^{6}$, Cela nos alerta para a origem dessa publicação. 0 livro se origina de uma série de 07 publicações, cada uma com 11 fotografias de Palazuelo, com nove relatos cada, entre 1965-1966 (Editorial Alfaguara). São pequenos fascículos, com capa fotográfica, com o título Nuevas Escenas Matritenses ${ }^{7}$, e o subtítulo Fotografías al minuto. Cela diz no prólogo do livro:

Estas fotografias al minuto se llamaron antes, cuando las publique em siete cuardenos sueltos de a nueve cada uno, Nuevas escenas matritenses, título que, si literario y arcaizante, era también - y quizá por eso - no poco desorientador y confuso... Para mí tengo que el título que ahora le doy es oportuno para la mercancía que brindo, ya que Henrique Palazuelo y yo - él por su lado y con sus artes y yo por el mío y com la mías - anduvimos por el Madrid de los años 50 tratando, con herramienta diferente, de buscar lo mismo: el latir que o tumultuário, resignado, sublevado y atónito, de la vida callejera, ese milagro de Diós produce cada mañana y - para mejor fortuna de todos - sin cansarse jámas de hacerlo". (CELA, 1972, p. 07)

Horácio Fernández realizou uma longa pesquisa sobre fotolivros espanhóis e organizou, como curador, uma longa exposição no Museo Reina Sofía (Madrid), entre 2004 e 2005, com incríveis quase oito meses de duração e que se intitulou "fotos \& libros. España 1905-1977". O texto de Fernández perpassa, mesmo sendo curto, a trajetória da relação entre literatura e fotografia em Cela. A coleção alavancada pela 
curadoria, hoje pertencente ao acervo do museu, incentivou o uso do temo fotolivro, que para o curador, é um lugar para a narratividade fotográfica em contraponto ao momento decisivo, e ao mesmo tempo, criando um lugar de arte como estratégia museológica, para esse produto editorial e gráfico, ou seja, um novo espaço para o fotográfico, agora como livro de arte, deixando uma condição subalterna, que ocultariam complexos e múltiplos discursos visuais, e muitas vezes articulados com a palavra. Nessa exposição, no seu cuidadoso e denso catálogo, a série Nuevas Escenas Matritenses teve grande destaque

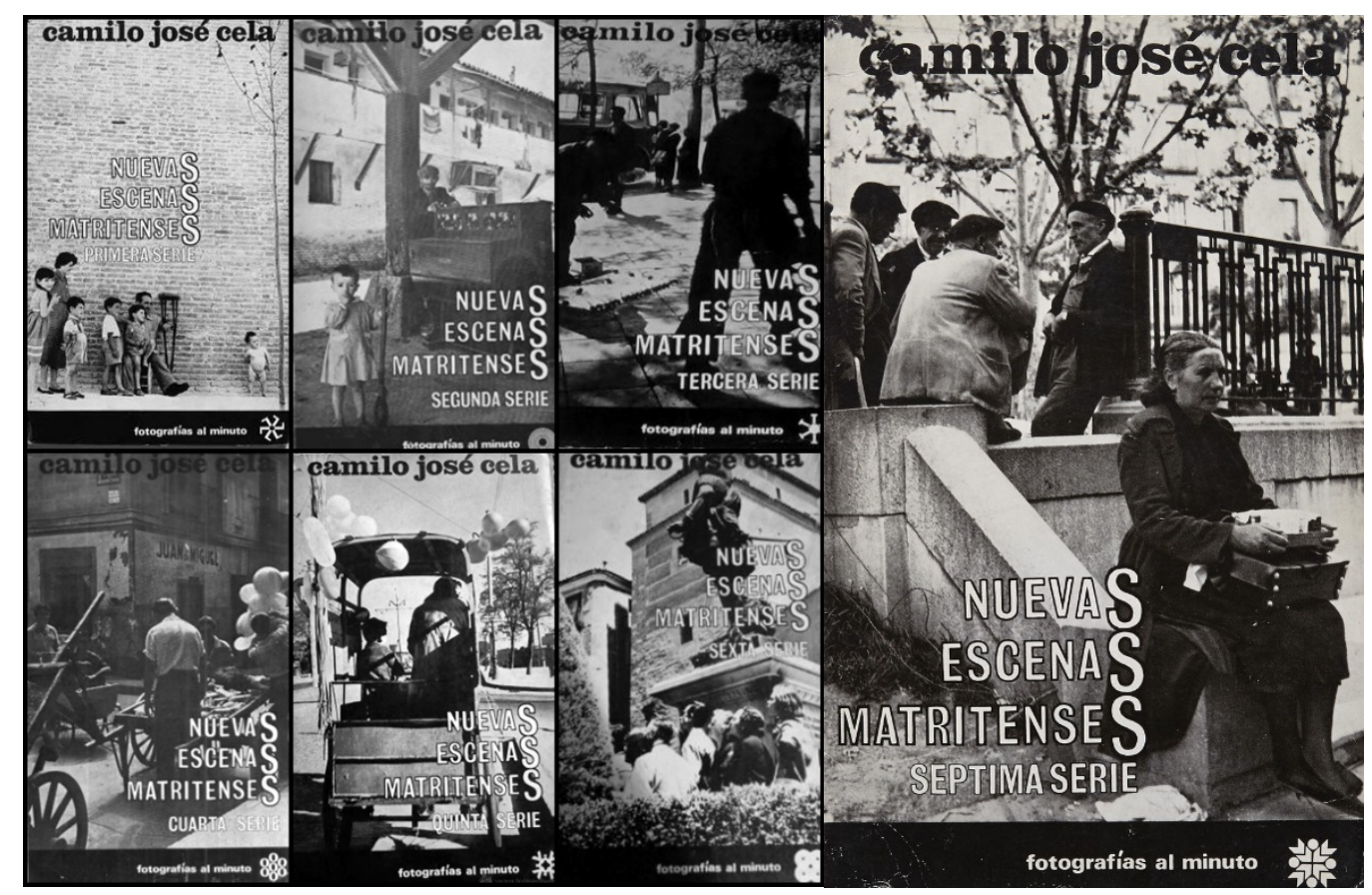

Figura 3 - Nuevas-escenas-matritenses

O texto do catálogo mostra uma pesquisa atenciosa sobre a série, ancorada em textos de época, carta entre Cela e Palazuelo, e a origem do projeto. Antes da publicação da série como pequenos livros, Cela publica em 1958 na revista Destino uma crônica, Nicasio Alcoba en la calle de las Huertas, com uma foto de Palazuelo. Esse relato é, obviamente, o primeiro do livro. Sobre Palazuelo, o texto do catálogo indica somente poucas informações sobre seu destino depois da publicação da série, indicando que é um teniente de navio, que gosta de viajar em seu pequeno veleiro, e se perdeu seu rumo 
pelas suas andanças marítima, até ser descoberto em Buenos Aires, onde morre em 1996. Cela também publica, sempre com fotos de Palazuelo, alguns dos relatos em sua revista literária Papeles de Son Armadans. Finalmente, depois de fundar o Editorial Alfaguara em 1963, irá publicar toda a série em sua editora nos anos 1965-1966. Aqui, podemos pensar que a ousadia de Cela, como escritor que se debruça sobre imagens, se alia a ousadia de projetos editorias. Nesses mesmos anos, 1963-64, Cela participará com duas produções dentro da paradigmática coleção Palabra e Imagen, do Editorial Lumen, que destacaremos mais adiante.

Podemos perceber uma relação direta com o flanerie de Baudelaire, nas andarilhagens que percorre fotógrafo pela cidade, e o flanerie fotográfico do escritor para encontrar cenas cotidianas e banais, mas com uma visão para o invisível da sociedade, ou o que não se quer valorizar. Como acentua Fernández, o arquivo de cópias de Palazuelo que se tem conhecimento é da ordem de 300 imagens:

En ellas no se presta atención a las relíquias históricas: no hay monumentos ni museos. Tampoco tienen cabida las novidades del Madrid reciente (las zonas más modernas y próperas da la capital) ni los tópicos fotográficos de costumbres (las imágenes de denuncia o los asuntos turísticos). (FERNÁNDEZ, 2004, p. 183)

Assim, os mercados (Rastro); lojas e vitrines, bairros não centrais, onde mulheres lavam roupas perto de seus casebres de madeira ou crianças brincam em prédios recém construídos na periferia; cenas internas de bares; as babás de crianças burguesas; uma série de ambulantes de rua; enfim, uma Madrid não monumental, não histórica, não turística, uma cidade escondida: El tema común es una ciudad oculta dentro de outra ciudad (Fernández, 2004, pag. 183). E também nos chama muito a atenção é a presença da escritura de Cela no próprio ato fotográfico, ou seja, Cela dá nome, idade, profissão de muitos dos retratados, além de discursar sobre suas preferências ou histórias pessoais, indicando a conjunção temporal entre cronista e fotógrafo. Ao flanar na imagem, Cela se aproxima do ato, ficcionando-o realisticamente, quase como uma reportagem. No relato que acompanha a foto $E l$ consejo de ancianos, Cela encontra uma moral desse possível conselho de sete pessoas mais velhas, para além das formalidades institucionais, inclusive com suplente: 
Por tradición, las hembras deben figurar en el consejo de ancianos, pero, también por tradición, las hembras del consejo de ancianos han de estar en minoria, o sea que debe uma, al menos, y pueden admitirse hasta dos o três, pero no más; este año, según salta a la vista, se sienta una anciana entre los jueces del consejo". (CELA, 1966, p. 155)

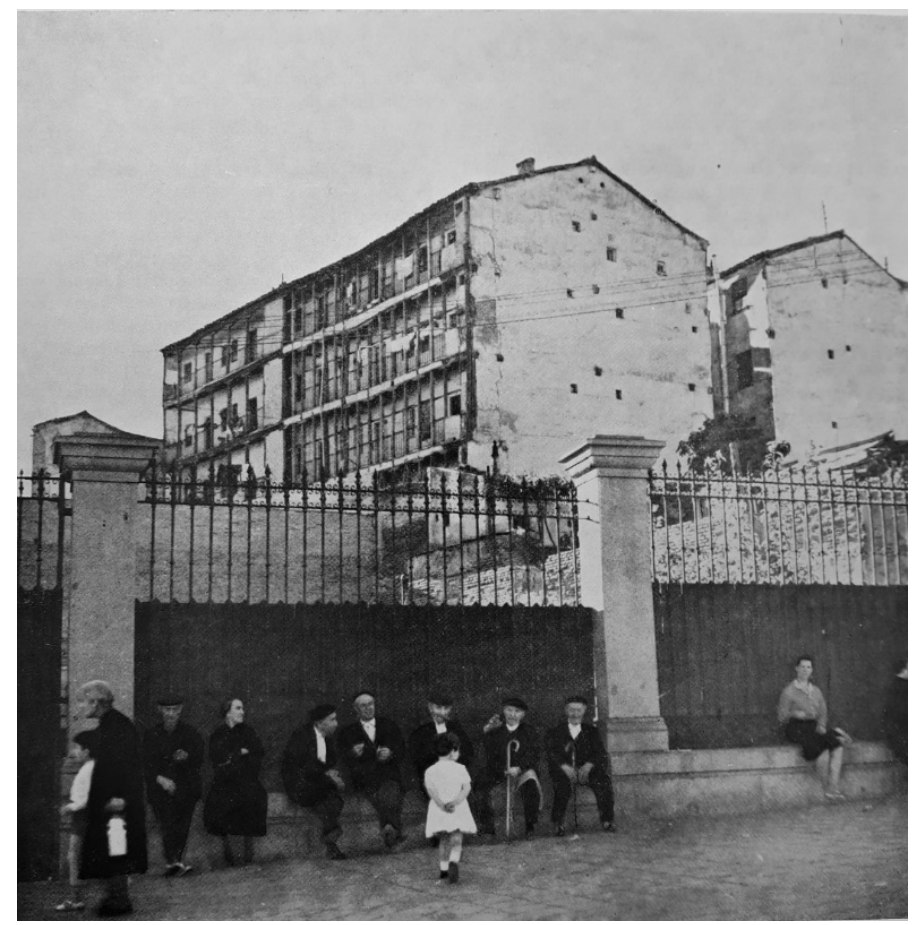

Figura 04 - Nuevas escenas matritenses.

Foto de Henrique Palazuelo

E em seguida, Cela irá nomear a todo conselho, suas idades, cidade natal, etc. E no caso da fotografia, uma ironia, estaria o conselho todo severo em trajes negros, sentados, e um deles, com bengala, levanta a mão para uma criança vestida de branco, em contraste cromático, que caminha inocentemente de costas para a câmera à frente do conselho, e prossegue Cela: Los sietes ciudadanos realengos que van a juzgar a la inculpada Rosita Rico Garganchón, de cuatro años de edad, por su presunto delito de sacamiento de lengua a sua tía Cloti...

Em Fotografía al minuto, Cela nomeia cada série como "carrete", ou rolo de filmes, como se cada uma das séries estivesse vinculada a uma seriação fotográfica, ou ainda, criando a ideia de temporalidades entre imagens. 0 título original das sete séries 
publicadas isoladamente, uma a uma, volta em publicação de 1988: Nuevas Escenas Matritenses, Editorial Circulo de Lectores: Barcelona, 1988.

Cela realizou uma série de doze relatos que Cela faz de também doze fotografias que o escritor recebeu de um fotógrafo ambulante, Sansón Garcia e que são publicadas na revista Destino, entre 1952 e 1954 com o título Doce fotografias al minuto, e depois publicadas no livro El gallego y su caudrilla. Fernádez ainda aponta que dois desses relatos foram publicados na importante revista fotográfica da AFAL, em 1957, e indica que esses relatos foram com um primeiro ensaio que deve ter originado a série de crônica matritenses.

Rodiek (2008) ${ }^{8}$, estudioso da narrativa breve em Cela, ao discorrer sobre esses doze relatos questiona ou encontra o lugar do narrador, quando o escritor descreve o encontro com o fotógrafo ambulante:

El narrados nos cuenta aqui, cuándo y dónde Sansón Garcia le entrego las fotos. Esto significa que, en momento dado, el narrador se encontraba como personaje en el mundo (diégesis) de Sansón Garcia. Semejante incursión le estaria naturalmente vedada a un narrador omnisciente, que se define por su carácter heterodiegético. Es decir, tras el 'firmante' se esconde un 'yo'. (RODIEK, 2008, p. 37)

O autor encontra, em seguida, então, no personagem Sansón, o próprio Cela escondido na narrativa do outro: "Para el interlocutor, Sansón es una persona con la cual se charla. Para el escritor, Sansón es un personaje que actua en un texto". Rodiek esclarece a existência de três fases e três atividades do relato: a primeira, o retrato fotográfico (Sansón); o segundo, os comentários verbais, também de Sansón; e por último, o relato elaborado pelo escritor. Para ele, o leitor somente tem acesso à terceira fase "...que contiene, como un palimpsesto, restos das versiones de Sansón. Podemos decir que lo característico de la narración en 'Doce fotografias al minuto' es la superposión de dos voces, la de Sansón y la del escritor" (2008, p. 38). Alguns exemplos desse encontro serão descritos e analisados no livro de Rodiek.

Assim, podemos entender a relação entre esses doze relatos e as sete séries de cenas matritenses, que ao contrário do relato de viagem (Alcarria), onde a "geografia", física e humana ancorava as realidades "del viajero" nas suas andanças, nessas propostas de 
breves relatos, o ficcional de sobrepõe ao documental. Rodiek conceitua esse procedimento como "fotorrelato celiano", no qual o escritor transpassa as cenas da realidade para criar personagens, e no caso dos doze relatos, a própria origem das imagens, o doador das fotos, se torna em um personagem camuflado do escritor.

El fotorrelato celiano, según nuestra definición, es un texto híbrido que abarca la reproducción de un trozo de realidad contemporánea (foto de una persona en su entorno social) y la biografia apócrifa de esa persona (texto). La extrema tensión entre lo documental de la foto y lo paródico de las palabras permite al lector saborear el irónico distanciamiento producido por la mirada creadora de Cela. Al mismo tiempo, el lector se siente instigado a producir una verbalización no paródica de la foto. (RODIEK, 2008, p. 07)

Fernández acentua que Cela cria uma relação enriquecedora da fotografia ao matizála na literatura, e entendemos, principalmente por criar um universo literário paralelo (fotorrelato celiano) e com um viés realista frente à própria imagem, e de certa forma, confundindo o leitor desavisado: "En lugar de observar la realidade diretamente atende a las fotos, aunque sin sentirser obligado a respetar su contenido" (2004, p. 184).

\section{Os fotolivros da Coleção Palabra e Imagen}

A coleção Palabra e Imagen, do editorial Lumen, publicou entre 1961 e 1975 dezenove livros que buscam intertextualidades entre literatura e fotografia e vice-versa. Todos livros tem em comum um projeto único no processo de criação, repetindo somente a forma quadrada, capa dura, e os tipos de papéis utilizados ${ }^{9}$. Dentre as publicações encontramos quatro prêmios Nobel de Literatura: Pablo Neruda (1971), Octavio Paz (1990), Camilo José Cela (1989), e Vargas Llosa (2010). Somente esse grupo de escritores presentes na coleção já a coloca entre as mais importantes com essa temática, e também pelos fotógrafos que participaram da mesma, espanhóis e outras nacionalidades.

Camilo José Cela participou da coleção com dois livros publicados respectivamente em 1963 e 1964: Toreo de salón. Farsa con acompañamiento de clamor y murga (fotos da dupla Oriol Maspons e Julio Ubiña); e "Izas, rabizas y colipoterras. Drama con acompañamiento de cachondeo y dolor de corazón", com fotos Juan Colom. Nessas duas publicações nota-se claramente as intencionalidades do "fotorrelato celiano", 
conforme conceituou Rodiek. As fotos de Oriol Maspons e Julio Ubiña, assim como as fotos de Juan Colom, foram feitas antes da escritura de Cela, que não participou diretamente da produção, somente as recebeu e criou suas ficções realísticas, tendo sido publicadas anteriormente em revistas de fotografia (revista AFAL) e já terem participado de exposições ${ }^{10}$ (Ortiz-Echagë, 2004).

A presença cultural da tauromaquia, principalmente dentro de um espaço não institucionalizado, em processos de aprendizagem improvisados, reforça os laços históricos desde Goya, e nesse caso específico com jovens esperançosos de um lugar na arena (torerillos ${ }^{11}$ ). Ortiz-Echagë em seu artigo indica uma inquietação de Cela com a visibilidade das imagens anteriores ao livro e se preocupa em escrever em sua revista, Papeles de Son Armadans, e seria inédito, com fotografias ainda não publicadas:

Con independência de los recelos del novelista, lo cierto es que no era la primera vez que aparecían impresas nas fotografias de los torerillos. Se publicaron por primeira vez en 1958, en las páginas de Gaceta Ilustrada, en un amplío reportaje sobre la escuela de toreo barcelonesa de Manuel Mateos, 'el Estremeño', en una de sus clases teóricas dedicadas a la 'enseñança geométrica del toreo' - que tenía lugar de 8 a 9 de la noche en diferentes tabernas, según los días - y se seguían con las prácticas de los domingos por la tarde en Plaza de Sol de Montjuic. (2004, p. 150)

Pensando o conjunto fotográfico como um todo, podemos deslocá-lo para o campo da antropologia, como um estudo etnográfico visual do ensino popular da tauromaquia, com seus signos, vestimentas, gestualidades e sociabilidade. Entretanto, na hibridização texto para a imagem, a ficção de Cela faz das fotografias um lugar de fantasia, para além das descrições do campo do studium barthesiano, ou seja, de um positivismo do visível. Esse deslocamento da imagem se apresenta logo na introdução (Introitus), quando o escritor exalta a dramaticidade da arte sem touros, ao dizer que é mais fácil torear um miura ${ }^{12}$ que fazer o toreo de salón. E finaliza: "Esto del toreo de salón es como la poesia pura o como el vicio solitário, algo que sólo es posible hallar entre los elegidos" (CELA, 1963, pag. s.n). Ao lado uma foto de uma porta de taberna, com o "toro", saindo para a rua, e não podemos deixar de associar essa imagem a Pablo Picasso (Calavera de toro, bronze, 1943), quando a cabeça do touro é um selim de 
bicicleta. Um convite da Picasso para um toreo de salón imaginário com uma obra de arte em metal e uma homenagem aos elegidos torerillos de Cela.

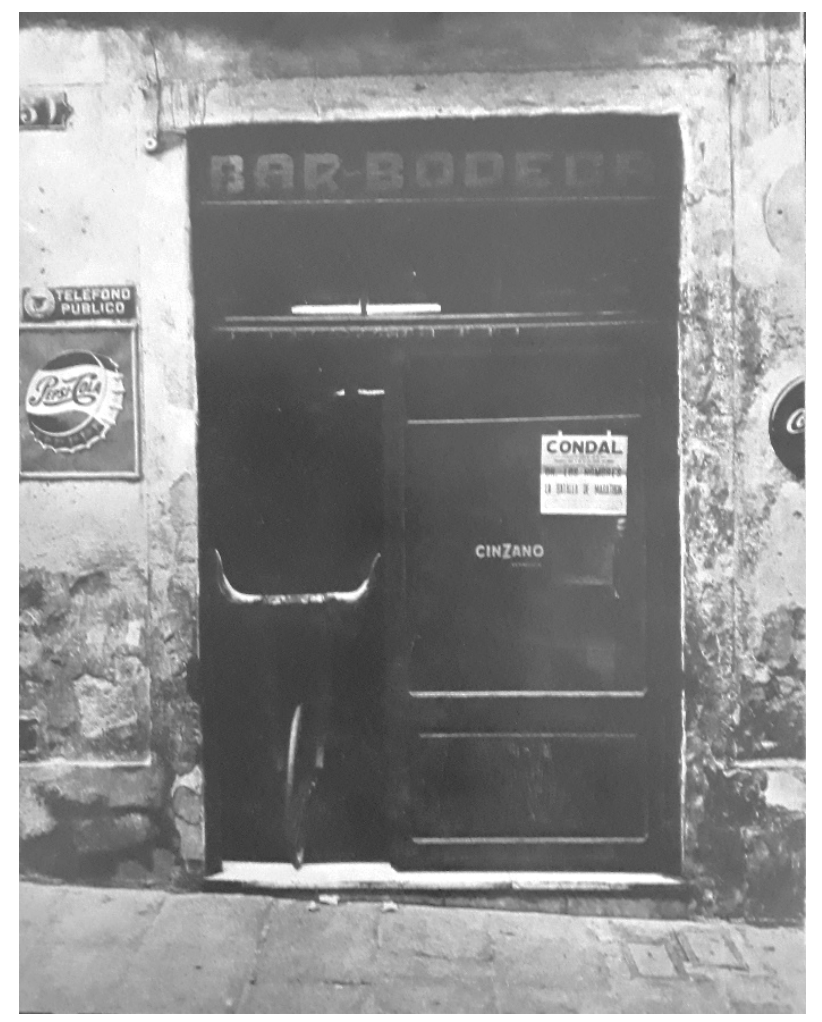

Figura 05 - Toreo de Salon. Foto de Maspons + Ubina

As divagações de Cela sobre as imagens ocorrem de uma a uma, introduzindo a iconografia das paredes e as sete espadas místicas penduradas na parede, a cada qual Cela lhe dá vida histórica. A página dupla se desdobra para que possamos vê-las saindo para um contracampo do livro, ação que se repetirá no design, em outras ocasiões. Em seguida apresentam-se os personagens em retratos, principalmente, ou em produções para o retrato. Em uma delas, no capítulo Petronius (nomeia aqui um torerillo de Petronio), e aparece seu retrato vestido de toureiro, e ao lado uma roupa que não é a sua, abre-se a página dupla e essa roupa que dialoga com Petronio vestico se desloca para seu contexto original, quando se vestem outros torerillos. Essa ousadia de formato em livro é original e diferencial, e também irá aparecer posteriormente no outro livro (Izas...). Na sequência, a conversa sobre a gestualidade, das proezas do corpo contra o "touro", introduz a sociabilidade entre eles, e a página dupla se 
desdobra em sequência temporal, para finalizar em uma imagem solitária de um torerillo e o toro de salón, uma concentração para a cena final.

As cenas em seguida incorporam as gestualidades internas da aprendizagem no recinto da taberna para as ruas e para as praças, agora em exibição pública. Essa presença pública já tinha sido apresentada em duas cenas anteriores, quando o touro saiu para a rua, onde existe mais espaço para a ação. Em uma delas, um plano superior, com o fotógrafo no plano superior de uma escadaria, podemos avistar uma longa rua, seus edifícios e as pessoas que observam as cenas. Cela irá nomeá-las, dar-lhes lugar com suas histórias particulares e familiares, ou seja, o escritor adentra a imagem pela observação da vizinhança. Aqui, a "exibição" pública é ensaio que transborda a porta da taberna. 0 etnográfico visual incorpora as relações sociais do bairro e da rua, como extensão de um vigor cultural da tauromaquia.

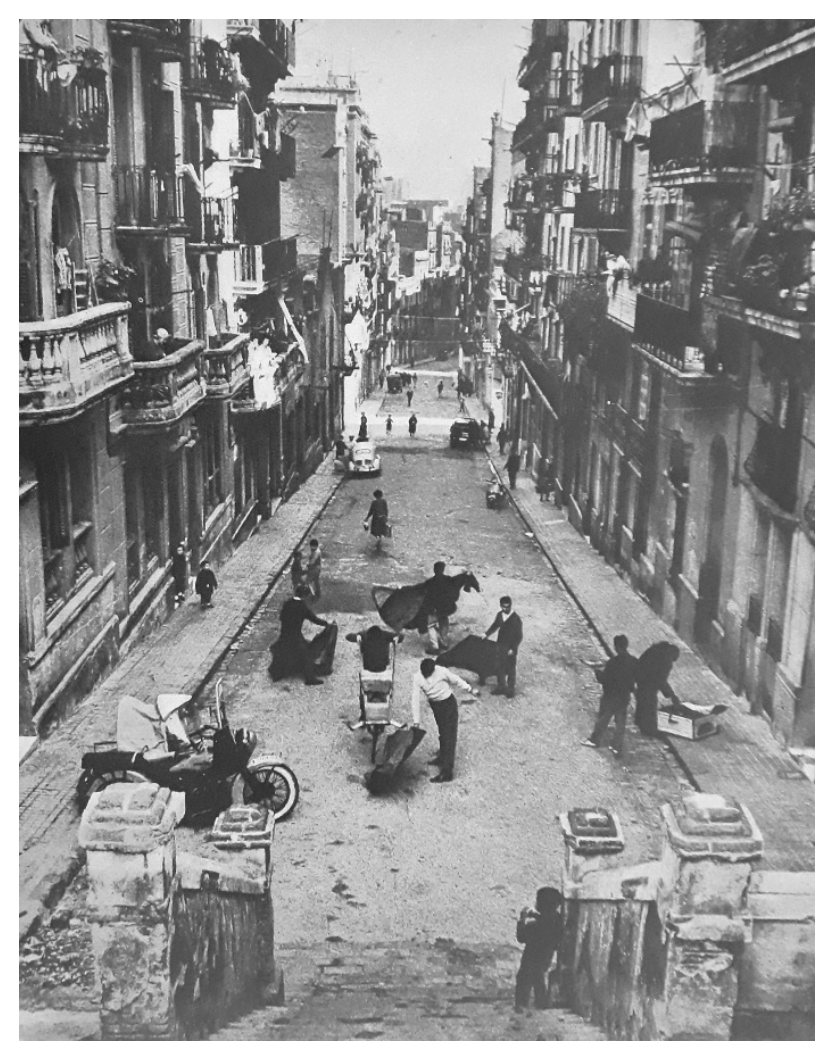

Figura 06 - Toreo de Salon. Foto de Maspons + Ubina 
Rodiek, depois de identificar uma "escritura paródica y deconstrutiva" e uma questionável aproximação com subjetividade do punctum de Barthes, o autor afirma que o fotorrelato celiano somente é possível no "...fuerte constraste entre la fotografia documental y la deformación verbal de la realidade reflejada en la imágenes", e com certeza, também afirma que essa "frutífera tensión" se perderia em edições sem as imagens ${ }^{13}$ :

Sólo en contacto con las fotos de Maspons y Ubiña la escritura irónica y caricaturesca de Cela puede desplegar el abanico de sus artifícios y efectos sutiles. La función de las fotos consiste en corregir y desmentir el carácter evidentemente apócrifo de los bosquejos biográficos de Cela. El flerte contraste entre foto y texto desconcierta el lector y, al mismo tiempo, lo intriga. Así, la lectura arbritraria de Cela provoca em el lector una lectura literal. (RODIEK, 2008, p. 105)

O final é apoteótico, na penúltima imagem, quando o touro salta no ar, com um deles, se fazendo de touro segurando os chifres em dramaticidade e acrobacia aérea, e abrindo a metade dobrada da página vemos o extracampo do livro, e a cena toda, com o revoar do capote encoberto pela espada - uma mística espada, uma das sete espadas -, e o torerillo em total harmonia gestual com o "touro", uma imagem épica; a consagração. A dinâmica das montagens gráficas, da criação de um extra livro, um livro objeto expandido em páginas para além do formato tradicional, descola o fotográfico do texto.
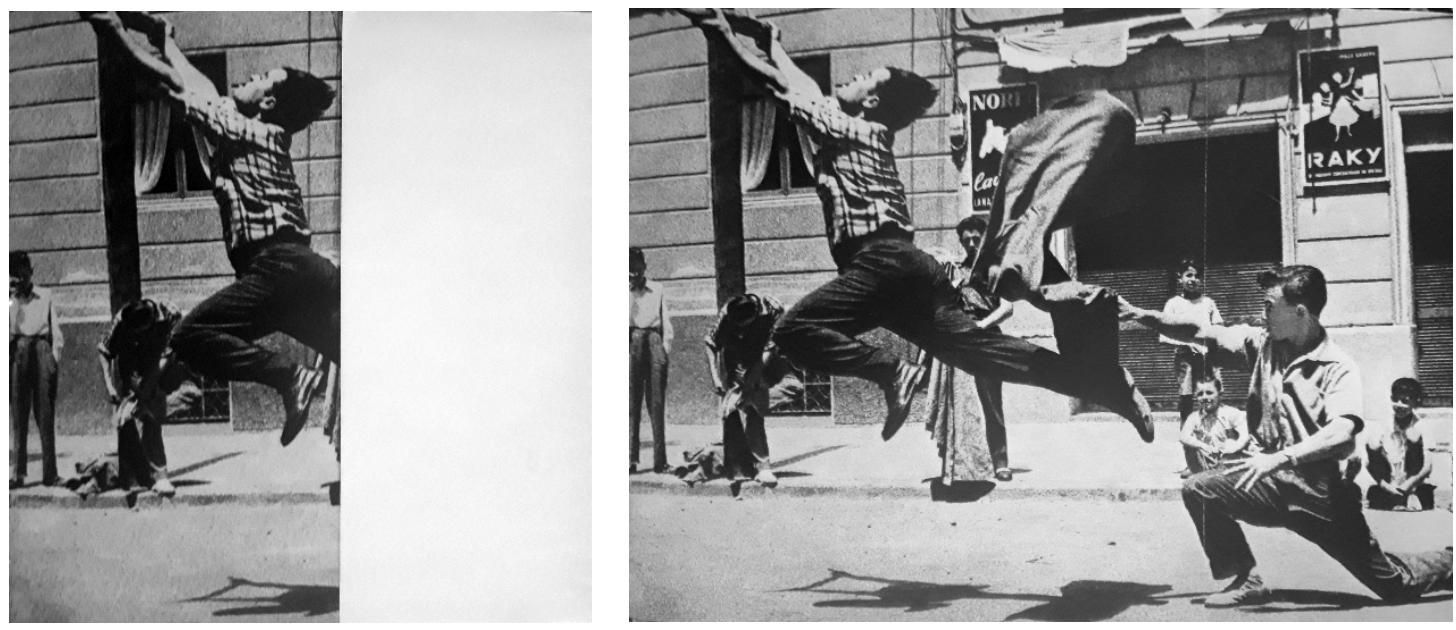

Figura 07 - Toreo de Salon. Foto de Maspons + Ubina 
No final, última imagem, um solitário e tradicional gorro de toureiro (montera) resta no chão, como se a montera esperasse o resultado, o torerillo que se tornou torero, e Cela lhe dá uma voz onipresente: "El toreo de salón es como el exame de consciência, y el dolor de corazón, y el propósito de no volver a pecar jamás: algo que no relumbra si nos es con los ojos cerrados" (CELA, 1963, s.n).

O segundo livro - Izas, Rabizas y Colipoterras. Dram con acompanamiento de cachondeo y dolor de corazón - com fotos de Juan Colom, mantém os aspectos do fotorrelato celiano conforme outras publicações. Essa publicação talvez seja a mais polêmica da coleção e a mais citada (além da anterior comentado, também se destaca Neutral Corner. Esquina neutral, com texto de Ignácio Aldecoa e fotos de Rámon Masats, de 1962). Izas (...) sempre é citado e encontramos três autores que se dedicaram analisar o livro. Joan Fontcuberta escreveu o primeiro texto mais aprofundado sobre a obra em 1998, depois o mesmo texto com modificações, espelhado no primeiro, retorna em para um catálogo de exposição de fotografias de Juan Cólom, em 2004, e finalmente publicado em livro em 2008 ${ }^{14}$. Outro texto mais aprofundado, trazendo questões próprias da área da literatura, é o já citado livro de Christoph Rodiek (2008), como uma continuação da análise de Toreo de Salón, e o terceiro, como parte do catálogo da exposição também já citada por Javier Ortiz-Echagë (2014), e que também escreveu no catálogo sobre Toreo de Salón.

Fontcuberta faz um breve relato da trajetória de Colom, principalmente pela formação na comumente da época de associações de fotografia, no caso APC - Associació Fotogràfica de Catalunya -, e no embate que ocorreu em muitas partes do mundo entre fotoclubistas em um debate entre uma fotografia artística e uma fotografia documental ${ }^{15}$. Como parte da associação participou de salões e sua exposição com o tema da rua ("El carrer"), mostrando cenas marginais à visualidade da época fez Esther Tusquets aproximar fotógrafo e escritor para o livro Izas (...). 0 livro, como bem indica Fontcuberta, se tornou um objeto de culto por várias razões. Primeiro pela temática, ou seja, nesse período franquista publica-se um livro sobre prostitutas, quando havia uma lei que proibia a profissão e as mulheres eram contratadas como garçonetes em bares para burlar a lei. Segundo, a forma furtiva que a maioria das fotos foram realizadas, com Colom camuflando o ato fotográfico para não ser descoberto e 
conseguir cenas que somente dessa maneira teriam o resultado esperado, com fotografias que foram feitas sem olhar no visor de sua Leica, como um sujeito que espia, ao mesmo tempo, vigia, e nos dá uma sensação de voyerismo, o que para a temática se enquadraria perfeitamente. Terceiro, claro, o impacto da publicação, com os textos de Cela que tentam adentrar a alma das pessoas, ficcionando realisticamente as cenas, nomeando as mulheres, dando-lhes contexto pessoal e local. Quarto, a reação de uma das fotografadas - essa questão passa por todos os textos citado acima, com mais ou menos desenvolvimento -, de uma das mulheres que entra na justiça, sentindo-se denegrida, e um tema muito ampliando na mídia, o que favorece a popularização do livro. Por último, a retirada de Colom da fotografia, afetado pela disputa e controvérsias do livro, e importante frisar que ele não era um fotógrafo profissional, que vivia da fotografia, e assim “Desde 1964, su obra quedó sumida en el silencio más absoluto" (Fontcuberta, 2008, pag.376), e continua o autor, dizendo que a redescoberta de sua obra, nos anos oitenta através de retrospectivas da fotografia dessa época, fizeram o fotógrafo ter vontades de apresentar seu acervo sobre a vida popular de Barcelona.

Em seu texto, Fontcuberta não analisa diretamente a relação entre texto e imagem, e traça mais um caminho sobre questões de gênero, trazendo outras produções sobre prostitutas, e um embate sobre questões de gênero, em obras que o olhar era feminino. Somente traz a questão do uso e da pesquisa de uso de sinônimos para a palavra prostituta, muitas já fora de uso corrente, ou de contextos sociais específicos, e também as tipologias pitorescas de Cela em quadros de aproximação de personalidade, e criando figuras linguísticas populares para essas mulheres.

Para Fontcuberta, o livro é singular, e ao mesmo tempo, pela presença de Cela gestionando e acentuando a questão da prostituição ( e também Maspons, que levou a proposta para Esther Tusquets), pois, quando o livro volta a ser debatido nos anos oitenta, faz motivação para a recuperação de um novo olhar sobre a obra de Colom, que para Fontcuberta, é muito mais ampla que o estigma do livro:

El libro es un monumento a muchas memorias y estrafica numerosas voces; es un libro formidable, un magnífico álbum de estampas furtivas. Pero no nos permite escuchar la voz de Colom en su verdadeiro timbre. En Izas, rabizas y colipoterras Colom no habla, le 
hacen hablar, y en esas circunstancias nos llega apenas su eco lejano. Tan sólo tomando consciência de esta situación nos encaminhá a remediarla. (2008, p. 385)

Rodiek (2008) conduz seu texto sobre Izas (...) buscando o lugar do escritor, e o encontra em contraponto com a imagem, mesmo com paralelismo com o livro Toreo de Salón, para o autor a diferença gritante é a forma em que foram feitas as imagens e acentua: "Mediante la lúcida confusión de dos tipos de comunicación (pragmática versus ficcional), Cela quiere probar dos cosas: que lo verbal es superior a lo visual y lo ficticio ao real" (2008, pag. 107). Esse autor adentra as relações estruturais do livro, sua composição em capítulos dedicados a cinco tipos de prostitutas (izas, rabizas, colipoterras, hurgamanderas y putaranas), e também subtipos. Ou seja, Cela procura uma aproximação com as fotografias classificando e ordenando para realizar uma tipologia de pessoas, e consequentemente, criar contextos para cada uma.

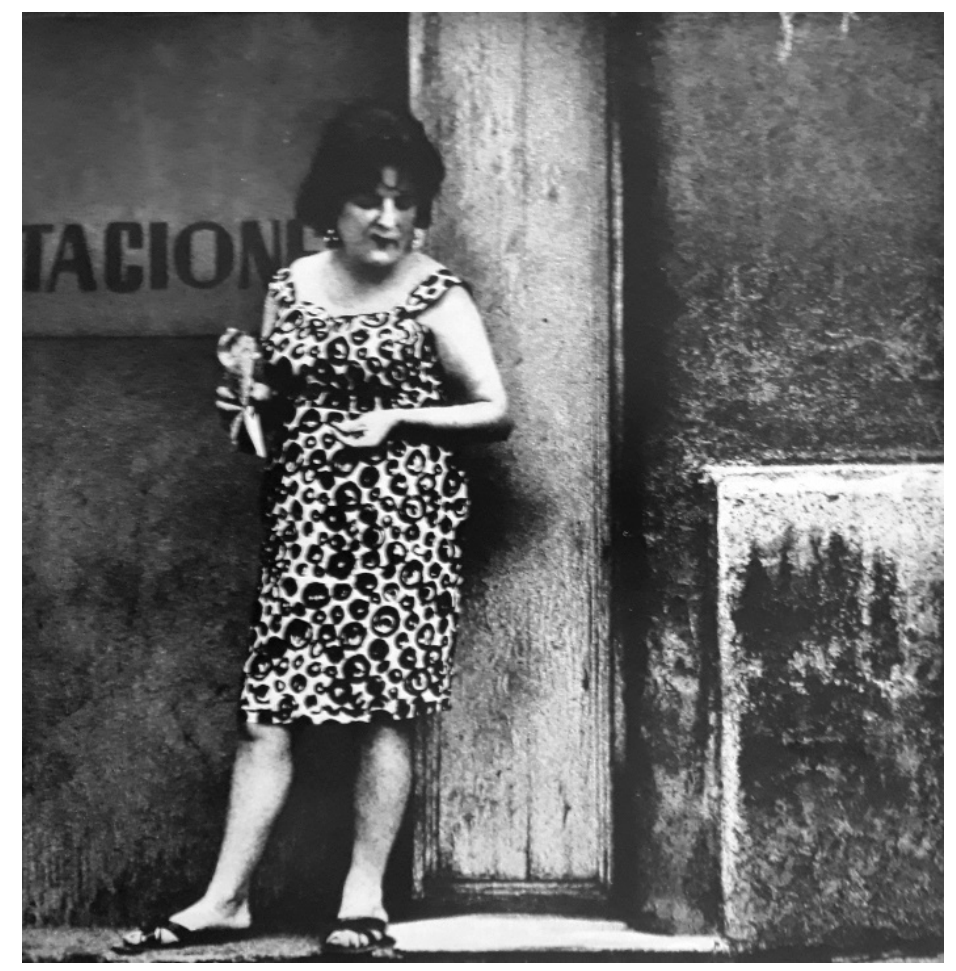

Figura 08 - Izas. Foto de Juan Colom

Em uma análise de um fotorrelato de Cela, chamado de "Chamicera comiendo pipa", Rodiek indica que Cela não procura aqui traços de personalidade da fotografada, e sim, 
procedendo de uma forma inversa. No texto de Cela, a chamicera ${ }^{16}$ é comparada aos pássaros "guacamayos" (araras, papagaios, maritacas), que gostam de sementes de girassol, como a mulher poderia estar também comendo. Lhe dá vida com a alegria das cores e de suas voze, ao mesmo tempo a aproximação com a reclusão e reprodutividade

Las chamiceras, como los guacamyos, Suelen vestir alegremente; tienden a taparse las carnes con ropages de vistosos colores...Las chamiceras, como los guacamayos, tienen la voz chillona y el pensamento ordenado en circunlóquios y otras artísticas volutas...Las chamiceras, como los guacamayos, son pájaros grandes y poderosos, que gastan la pólvora en salvas pero que pueden vivir y hasta reproducirse en cautividad". (CELA, 1964, p. 69-70)

Entretanto, o autor incorre, aqui e em outras passagens, em uma aproximação com o punctum barthesiano, que ao meu ver é uma distorção das subjetividades que o pensador francês faz na imersão pessoal em imagens íntimas ou distantes. Rodiek, ao encontrar punctum na escritura de Cela, talvez esteja procurando seu próprio punctum, sua própria subjetividade entre texto e imagem, e Barthes, ao sugerir o “conceito", vai de encontro à própria imagem e ao processo de transformação que a mesma lhe afeta e lhe angustia. No texto de Cela não tem angústia autoral, nem tampouco transformação "punctiana". Entretanto, tal sugestão do autor, não implica em perda de valor analítico, ao contrário, o texto de Rodiek não se prende a essa questão, e percorre os muitos fotorrelatos de Cela com precisão e detalhamento que o torna, a meu ver, o texto mais profícuo sobre a obra. E assim define, em meu recorte de seu texto, uma expressão que demarca a relação texto e fotografia:

En los fotorrelados de Cela, las contradicciones afectan sobre todo a las personas fotografiadas a traición y convertidas en habitantes de mundos imposibles. Se les atribuye una série de predicados sumamente arbitrários y - la más de las veces - nada halagënos. Aunque se destruya toda ilusión de realismo, el lector tiene la impresión de que el virtuosismo celiano raya en el abuso. (RODEIK, 2008, p. 111 - grifos do autor)

No campo fotográfico, a proposta gráfica também traz, assim como em Toreo de Salón, uma página dupla se desdobra e apresenta uma sequência de cinco imagens, uma "perseguição" de Colom a uma das mulheres (Tranco de las izas), e essa sequência 
escapa da escritura, pela temporalidade e pela própria dinâmica e ordenação da relação entre texto e imagem de uma mulher. Esse foco na figura feminina, por outro lado, aparece algumas vezes quando um recorte somente do rosto feminino se destaca em outra imagem, assim, reforça a relação direta com a caracterização que o escritor lhe fornece, quando a imagem abre o capítulo e o recorte o encerra em página com bordas brancas amplas, e a imagem agora centralizada no meio da página.

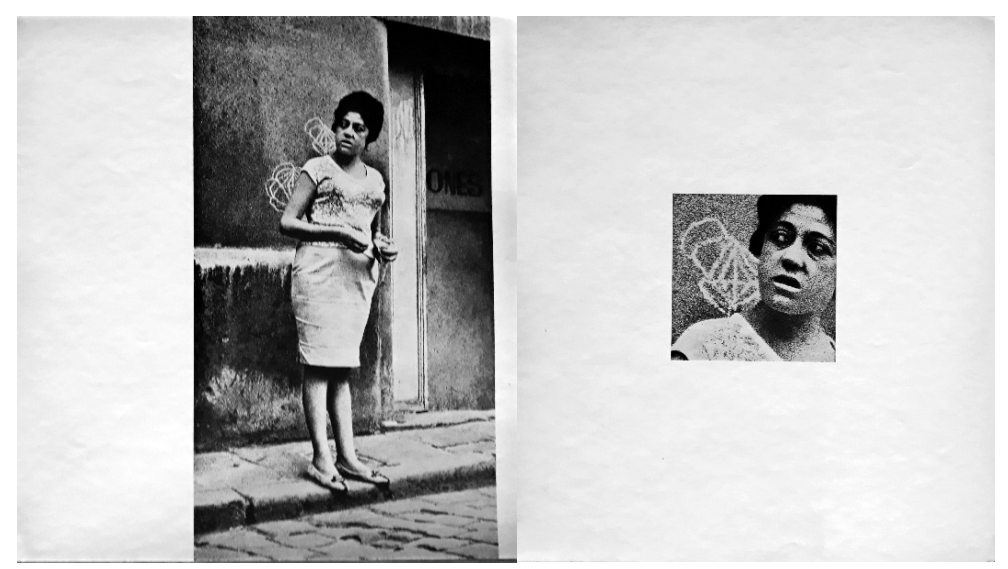

Figura 09 - Izas. Foto de Juan Colom

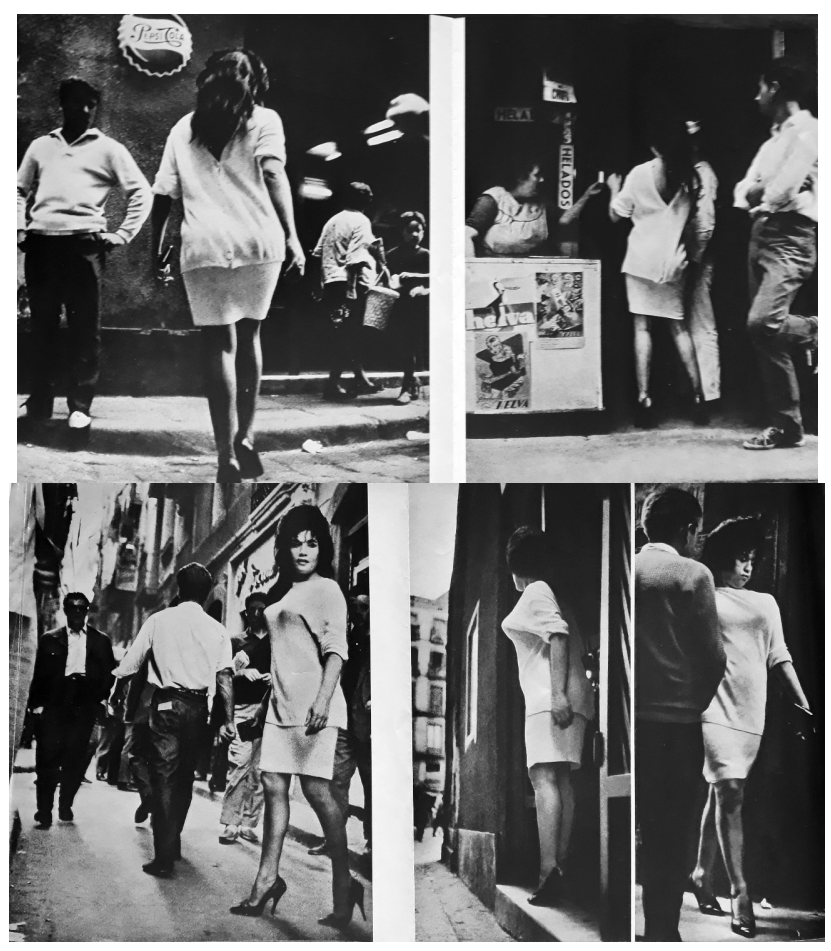

Figuras 10 e 11 - Izas. Foto de Juan Colom 
Ortiz-Echagë no texto do catálogo citado acima reforça a interferência de Cela na escolhas das imagens, o que deixou Colom magoado por ser somente uma parte de seu trabalho, e o título escolhido pelo escritor: “Cuando recebió las fotografias, Cela asumió la responsabilidade de la selección, estableció la secuencia ... el libro resultante es más obra de Cela que de Colom" (2014, p. 164). Para além dos outros autores, Ortiz-Echagë encontra em uma passagem de um livro de Cela a inspiração para o título (um verso de seu livro Cancioneiro general de Amberes), e também percorre alguns dos exemplos do livro para afirmar que as descrições de Cela são "satyricas y arbitrárias", e um detalhe muito interessante da vida de Cela nos anos quarenta quando exerceu o trabalho de censor, e nesse sentido facilitou a publicação do livro com a polêmica temática em tempos franquistas. ${ }^{17} \mathrm{E}$ ainda nos informa que a excelente $\mathrm{e}$ paradigmática capa com tiras de folha contato de negativos, que passam da capa para a contracapa, somente foi pensada depois de descartada uma fotografia, que poderia ser provocativa, e assim ficou uma capa mais neutra. 0 livro ser tonou o livro mais vendido do Editorial Lumen e da coleção Palabra e Imagen.

O que perpassa todos esses autores aqui citados é a importância desse livro, na coleção do Editorial Lumen, e principalmente, na história do fotolivro espanhol e internacional. E nesse sentido, importante lembrar aqui também a geniosa construção do sumário ao final em forma de círculos, com a volta de todas as imagens como marcadores, mesmo com o sumário tradicional ao lado, o que nos demonstra a liberdade criativa para o design do livro objeto que se tornou Izas (...). O livro, e todas suas relações, consequências e histórias, celebra a relação efetiva que Cela cultivou com a fotografia e seus fotorrelatos, e se pensarmos temporalmente, nos parece que essa relação entre muitas idas e vindas na publicações, muitas delas próximas, entre 1948 e 1966, e me lembra uma passagem de um filme sobre um fotógrafo e sobre fotografia (Before the rain, de Milcho Manchevski, 1995), e a premissa principal que transpassa a narrativa: o tempo não para, o círculo não é redondo. 


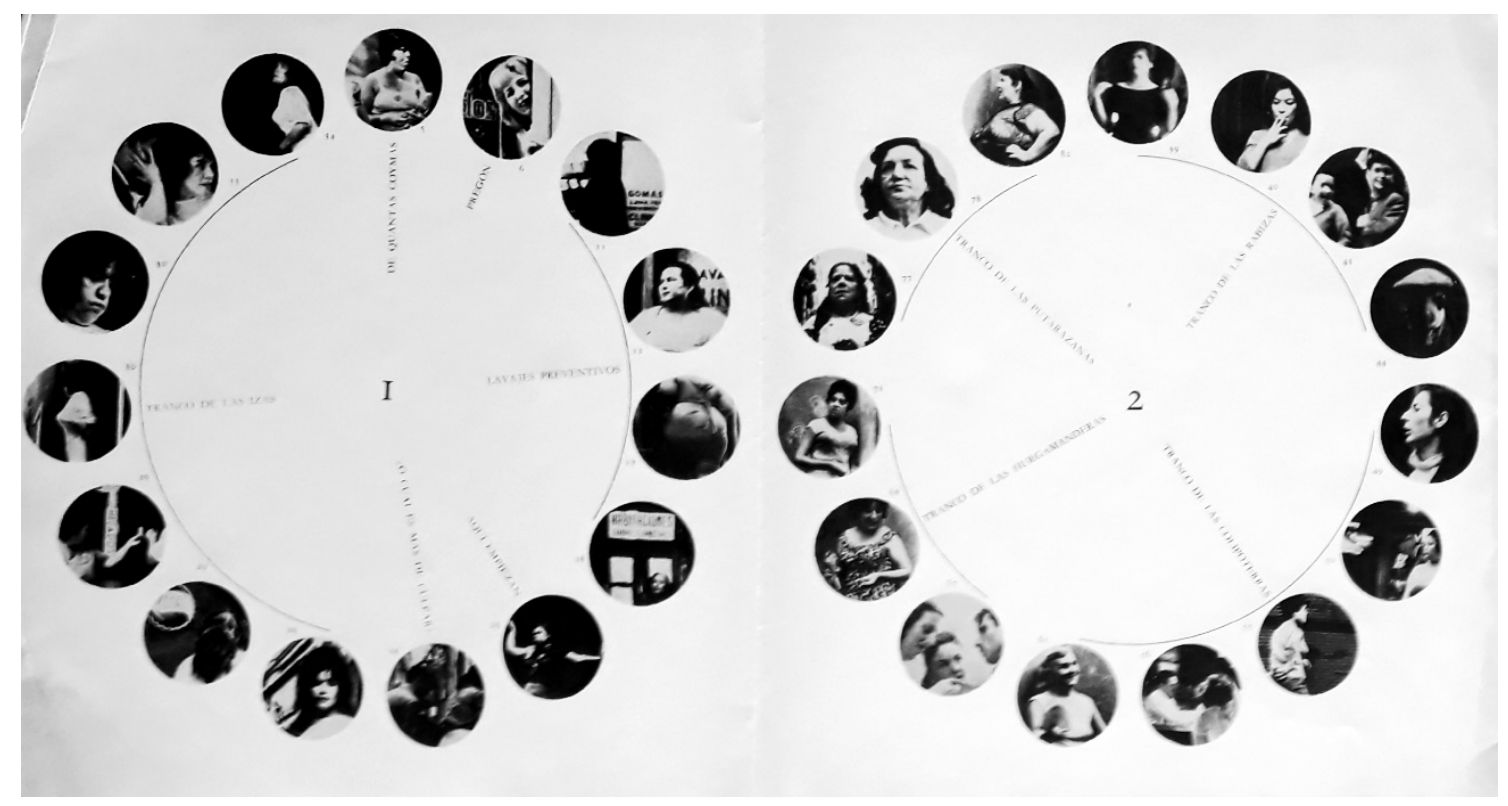

Imagem 12 - Izas. Foto de Juan Colom (Diseño Cristián Cirici y Oscar Tusquets) 


\section{Referencias}

CELA, Camilo José. "Elogio de la fotografía". En Cajón de sastre, Obra completa, tomo 12. Barcelona: Ediciones Destino, 1990. pp. 322-325, publicado pela primeira vez na Revista Arriba, 13/01/1948.

CELA, Camilo José (Fotografias de Karl Wlasak). Viaje a la Alcarria. Barcelona: Editorial Alfaguara, 1966.

CELA, Camilo José (fotografias de Henrique Palazuelo). Fotografías al minuto. Madrid: Editoral Sala, 1972.

CELA, Camilo José (fotografias de Henrique Palazuelo). El gallego y su caudrilla. Barcelona: Editorial Destino 1955.

FERNÁNDEZ, Horácio \& Ortiz-Echagë, Javier. Fotos \& libros, España 1905 -1997, Museo Reina Sofia: Madrid, 2014 (catálogo)

FONTCUBERTA, Joan. "Izas, rabizas y colipoterras: un álbum furtivo”, In Historias de la Fotografía Española - escritos 1977-2004. Barcelona: Gustavo Gili, 2008. pp. 375-385.

ORTIZ-ECHAGË, Javier. “Toreo de salón” In FERNÁNDEZ, Horácio \& Ortiz-Echagë, Javier. Fotos \& libros, España 1905 -1997, Museo Reina Sofia: Madrid, 2014 (catálogo), pp. 150-152.

SCHOMMER, Alberto. "Elogio a la Fotografía" In Recepción Publica, Real Academia de Bellas Artes de San Fernando (26 de abril de 1998).

RODIEK, Christoph. Del cuento al relato híbrido: en torno a la narrativa breve de Camilo José Cela. Madrid: Editorial Iberoamericana, 2008.

VÁZQUEZ, Adolfo Sotelo. Camilo José Cela, Perfiles de un escritor. Sevilla: Editorial Renacimiento, 2008.

\section{Notas}

\footnotetext{
1 Revista Arriba, 13/01/1948.

2 Cela, Camilo José. "Elogio de la fotografía". En Cajón de sastre, Obra completa, tomo 12. Barcelona: Ediciones Destino, 1990. Págs. 322-325.

${ }^{3}$ Nicolás Muller foi um fotógrafo húngaro, nacionalizado espanhol (1913 - 2000), com vasta produção e colaboração com escritores espanhóis em edição de livros ilustrados sobre lugares importantes da Espanha (Catalunha, País Vasco, Cantábria, Baleares, Canárias, Andaluzia).
} 
${ }^{4} \mathrm{O}$ tremedismo se desenvolveu na literatura espanhola dos anos quarenta, e se caracteriza por um realismo que se defronta com os marginalizados, esquecidos, ou pouco lembrados personagens de situações de vida dura, com aspereza no desenvolvimento da novela.

${ }^{5}$ El Extramundi y los papeles de Iria Flavia, revista da Fundación Camilo José Cela, número 46 (2006), traz um texto de Camilo José Cela ("Guadalajara"); outro texto de Adolfo Sotelo Vázquez ("Viaje a la Alcarria: génesis y recepción"); e 60 fotos de Karl Wlask. A revista foi fundada em 1995 pelo próprio Camilo José Cela (em cujo editorial do primeiro número recorda sua referencial revista de criação literária Papeles de Son Armadans (1956-1979), cujo título remete ao bairro que morava em Palma de Mallorca. Iria Flavia é um pequeno pueblo, pertencente à cidade de Padrón, na província galega de A Coruña.

${ }^{6}$ Descarriado; adjetivo, atualmente de pouco uso, que no contexto significa desorientado, perdido ou desavisado.

${ }^{7}$ Matritense; adjetivo, que pertence ou é relativo a Madrid.

${ }^{8}$ A foto da capa do livro é de autoria de Julio Ubiña, e publicado no livro Toreo de Salón, do Editorial Lumen, na coleção Palabra e Imagen, em 1963, com texto de Camilo José Cela, e também com fotos de Oriol Maspons.

${ }^{9}$ Sugiro me artigo que aborda a origem e o processo de cada livro no artigo "Entre Palabra e Imagen A coleção do Editorial Lumen", disponível em:

https://www.studium.iar.unicamp.br/40/09/index.html

${ }^{10}$ A importância do grupo AFAL foi recentemente tema de uma doação ao Museo Reina Sofia (2018-

2019). "Una aproximación a Afal. Donación Autric-Tamayo".

https://www.museoreinasofia.es/prensa/nota-de-prensa/grupo-afal-son-realidad-no-son-temas

${ }^{11}$ Se refere aos iniciantes à prática da tourada, ou da corrida de toros.

12 Miura é um tipo específico de toro criado por gerações desde 1842 e sua criação é tradicional da Andaluzia.

${ }^{13}$ A editora Lumen lançou nova edição do livro na Coleção Palabra Menor, em 1984, com uma diagramação diferente e redutora da primeira edição, perdendo suas ousadas características originais. 14 "Izas, rabizas y colipoterras: un àlbum furtiu", Catalan Review, Vol. XVIII, number 1-2, (1998), p. 181190 (em catalão), publicado posteriormente no catálogo referente à exposição ఏoan Colom. Fotografías de Barcelona 1958-1964, Lunwerg-Ministerio, 2004, pp. 45-51. E finalmente publicado com o mesmo título em espanhol "Izas, rabizas y colipoterras: un álbum furtivo" na coletânea de ensaios de Fontcuberta: Historias de la Fotografía Española - escritos 1977-2004, Gustavo Gili: Barcelona, 2008, pp. 375-385.

${ }_{15}$ Fontcuberta coloca as duas vertentes entre aspas.

${ }^{16}$ Que se refere a chamizo, casa miserável.

$17 \mathrm{O}$ autor cita uma passagem do informe do censor do livro que o qualificou como repugnante, entretanto não reconheceu no livro uma "incitação ao mau". 